\title{
Biodiversity of insects associated with safflower (Carthamus tinctorius) crop in Gachsaran, Iran
}

\author{
K. Saeidi, ${ }^{\text {S. Mirfakhraei, }}{ }^{2}$ F. Mehrkhou, ${ }^{2}$ O. Valizadegan² \\ 'Department of Plant Protection, Agricultural and Natural Resources Research and \\ Education Center, Kohgiluyeh va Boyerahmad Province, Yasouj; ${ }^{2}$ Department of Plant \\ Protection, College of Agriculture, Urmia University, Urmia, Iran
}

\begin{abstract}
The present research conducted to see the biodiversity of insects in warm and cool areas from March to April in 2009 at the Gachsaran Agricultural Research Station. A total number of 4261 specimens, which were identified into 31 families and 92 species. Out of total 31 families collected, 10 families were pests, 2 families belongs to predators and beneficial insects and 7 families belongs to parasitoids and beneficial insects and finally, 12 families of insects are saprophage and polyphagous. There was no significant difference $(\mathrm{P}>0.05)$ in the number of insects collected between months. The mean number of insects collected in the month of March, April and May was 34.7, 30.7 and 36.2 respectively. The Basht area is most susceptible host for insects (37.9), while the Gachsaran and Lishter areas is less susceptible (33.5) and (28.4) so both sites not differ significantly in the population of insects. The family Coccinellidae had more population in the Gachsaran-safflower zone (98.3) than the Basht-safflower zone (54.6) and it was significantly similar to the family cicadellidae. Similarly, different families like Aphididae (98.0), Cicadellidae (74), Thripidae (50.0), Curculionidae (26.6), Noctuidae (25.0) and Torymidae (27.3) had higher population in the Gachsaran-safflower zone than in the Basht-safflower area with means of 92.3, 63.0, 42.6, 21.0, 21.6 and 19.3 respectively. Also the families like Nymphalide, Pieridae, Lygaeidae, Papilionidae, Miridae, Pentatomidae, Reduviidae, Geometridae, Gryllotalpidae,
\end{abstract}

Correspondence: Karim Saeidi, Department of Plant Protection, Agricultural and Natural Resources Research and Education Center, Kohgiluyeh va Boyerahmad Province, P.0. Box 351, Yasouj, Iran.

Tel.: +98.74.33334821/+98.74.33334592 - Fax: +98.74 .33334011 .

E-mail: saeidi391@yahoo.com

Key words: Gachsaran; insects; diversity; Iran.

Received for publication: 5 September 2013.

Revision received: 9 November 2014.

Accepted for publication: 16 January 2015.

(C) Copyright K. Saeidi et al., 2015

Licensee PAGEPress, Italy

Journal of Entomological and Acarological Research 2015; 47:1910

doi:10.4081/jear.2015.1910

This article is distributed under the terms of the Creative Commons Attribution Noncommercial License (by-nc 3.0) which permits any noncommercial use, distribution, and reproduction in any medium, provided the original author(s) and source are credited.
Mantidae, Acrididae, Saturnidae and Anthocoridae had mean population of 12.6, 7.4, 12.0, 4.1, 4.4, 8.6, 1.9, 0.5, 7.5, 2.4, 11.3, 3.3 and 8.9.

\section{Introduction}

Insects are the most diverse group of organisms on the planet with over one million described species until now (Borror et al., 1989). However, these numbers represent less than the actual species richness of insects (Gullan \& Cranston, 2005). Species richness provides an extremely useful measurement of diversity where a complete catalogue of species in the community is obtained (Ahmed et al., 2004). Biodiversity is not only an issue of curiosity, but stands firm on the political agenda as a resource for humanity (Heywood, 1996). One of the key features of this agricultural intensification is the crop specialization in the production process, resulting in reduction in the number of crop species, often leading to monoculture. Monoculture rendering the system unstable, gives way to pest attack on crop that may lead to total collapse of the crop. Stability refers to constancy of system in which pest populations are kept at the level below those causing economic crop loss (Way \& Heong, 1994). Swift and Ingram (1996) and some others are of the view that the low planned diversity of crop systems is critical not only in terms of production but also it is an important determinant of the total biodiversity. It influences the compositions and abundance of the associated biota such as those of the pest complex and the soil insects and microorganisms, which in turn affect plant and soil processes. Insects have great potential for understanding ecosystem as measures of ecosystem health, but the incompleteness of knowledge and the limitation of resources increase the difficulty of work on insect biodiversity (Spellerberg \& Fedor, 2003). In Iran there are only three-reported insect's pests of safflower, namely Oxycarenus pallens $\mathrm{H}$. Sch. and Oxycarenus hyalipennis Costa (Hemiptera: Lygaeidae), and Acanthiophilus helianthi Rossi (Diptera: Tephritidae) (Behdad, 1989; Modaressaval, 1994).

In the Asia about 24 insect species associated with safflower comprising of Coleoptera (14 spp.), Diptera (4 spp.), Homoptera (1 spp.), Hemiptera (2 spp.), Lepidoptera (2 spp.) and one species of Thysanoptera (Campobasso et al., 1999). In Iraq, 23 species of safflower pests have been reported including 11 coleopteran species, 6 hemipteran species, 2 dipteran species, 2 thysanopteran species, 1 lepidopteran species, and 1 isopteran species (Selim, 1978).

In India, there are 15 species and 5 genera of insects and one species of mite recorded as the pests of the safflower (Anon, 1987). In Tooskani region, two agents, namely rust of the safflower and the safflower capsule fly, were of the destructive agents to the safflower (Sakra, 1999). In Egypt, the safflower capsule fly is one of the most 
important pests of the safflower, which is attacked by three species of parasitoid wasps from the families of Eulophidae (Pronatalia sp.) Torymidae (Antistrophophlex conthurnatus) and Pteromalidae (Pteromalus sp.) (Hegazi \& Moursi, 1983). According to Giray (1979), the safflower capsule fly can also attack the Xanthium spihosum, which is medicinally significant. In the study on the species from the genus Chaetorellia (Dip.: Tephritidae) the species Ch. carthami, Stackelberg was reported as the safflower pest common to such countries as Iraq, Israel, and Kirgizstan (Gharali \& Joozian, 2001).

In India, Safflower has been reported to be attacked by 36 species of pests (Bharaj et al., 2003). Out of these the safflower aphid, Uroleucon compositae (Theobald), capsule borer, Helicoverpa armigera (Hubner) and leaf eating caterpillar, Perigea capensis (Walker) are considered to be major pests of the crop in northern parts of Karnataka (Bharaj et al., 2003). The Safflower aphid alone is one of the most destructive pests reported to cause 35 to 72 per cent loss in yield during heavy infestation period (Ishaq et al., 2004). Survey results indicated that in general the intensity of $H$. armigera was more wherever safflower was sown as sole crop and intercropped with Bengal gram (Nasreen et al., 2004).

As previously no work has been done on the insect fauna of safflower and biodiversity of insects associated with safflower crop in Kohgiluyeh va Boyerahmad province, south west of Iran. Therefore, the present research studies were focused to collect, identify and compare the insect's fauna of safflower and the natural enemies of safflower capsule fly in Gachsaran, Kohgiluyeh va Boyerahmad province.

\section{Materials and methods}

\section{Sample collection for insect fauna of safflower}

Based on different cropping patterns and agro climatic conditions, safflower cultivation in Kohgiluyeh va Boyerahmad province (Figure 1) is classified into three major zones. The samplings were specifically conducted at Gachsaran Agriculture Research Station, Basht and Lishter. These represented Gachsaran-safflower zone, Basht-safflower zone and Lishter-safflower zone, respectively (Figure 1). The three localities were at least 15-20 km apart from each other.

The size of each site was 2000 square meters (one hundred square meters long and twenty square meters width). Sampling was conducted once a week from early March to end May 2008. Three methods of insect sampling were employed namely sweep netting, yellow sticky traps (especially for flying insects) and pit fall traps.

A total of 10 sweeps per site was done. A sweep is made by swinging the net through the crop canopy so the top of the net was at crop height. At the end of last sweep immediately swing the net quickly back and forth through the air well above the canopy to force the insects to the bottom of the net. Samples were then transferred to a universal bottle and brought back to the laboratory for further identification and the number of trapped insects was recorded.

A total of ten yellow sticky traps were set up per sites. Yellow sticky traps were composed of polyethylene plates with dimensions $20 \times 20 \mathrm{~cm}$. The traps were set up $1.5 \mathrm{~m}$ from ground level; oriented to the southwest and separated from each other by $200 \mathrm{~m}$. Traps were checked once a week during all the trial. Insects trapped in each trap were counted and removed after each sampling. Yellow sticky traps in each study had been fully cleaned and if necessary re-glued.

Ten pitfall traps per site were set up. Pitfall traps were placed in the middle and sides of the study site. Pitfall traps were dustbin of 8-inch diametre and 12 inch height, buried in the soil. Each trap was laid in such a way that the tip of the traps leveled to the surface of the ground. Ten percent formaline solutions were used in these pitfall traps and the number of trapped insects was recorded.

\section{Data analysis}

The comparison of insect fauna within months and sites were analyzed subjected to one-way analysis of variance (ANOVA). The means obtained were compared by Duncan's multiple range test at $5 \%$ level of probability.

\section{Results and discussion}

\section{Insect fauna of safflower}

A total of 4261 specimens of various insects were collected from three sites. The collected specimens comprised of 31 families and 92 species of insects (Table 1). Out of total 31 families collected, 10 families were pests, 2 families belongs to predators and beneficial insects and 7 families belongs to parasitoids and beneficial insects and finally, 12 families of insects are saprophage and polyphagous. There was no significant difference $(\mathrm{P}>0.05)$ in the number of insects collected between months. The mean number of insects collected in the month of March, April and May was 34.7, 30.7 and 36.2 respectively (Figure 2). The Basht area is most susceptible host for insects (37.9), while the Gachsaran and Lishter areas are less susceptible (33.5) and (28.4) so both sites not differ significantly in the population of insects (Figure 3 ).

The family Coccinellidae had more population in the Gachsaran-safflower zone (98.3) than the Basht-safflower zone (54.6) and it was significantly similar to the family cicadellidae. Similarly, different families like Aphididae (98.0), Cicadellidae (74), Thripidae (50.0), Curculionidae

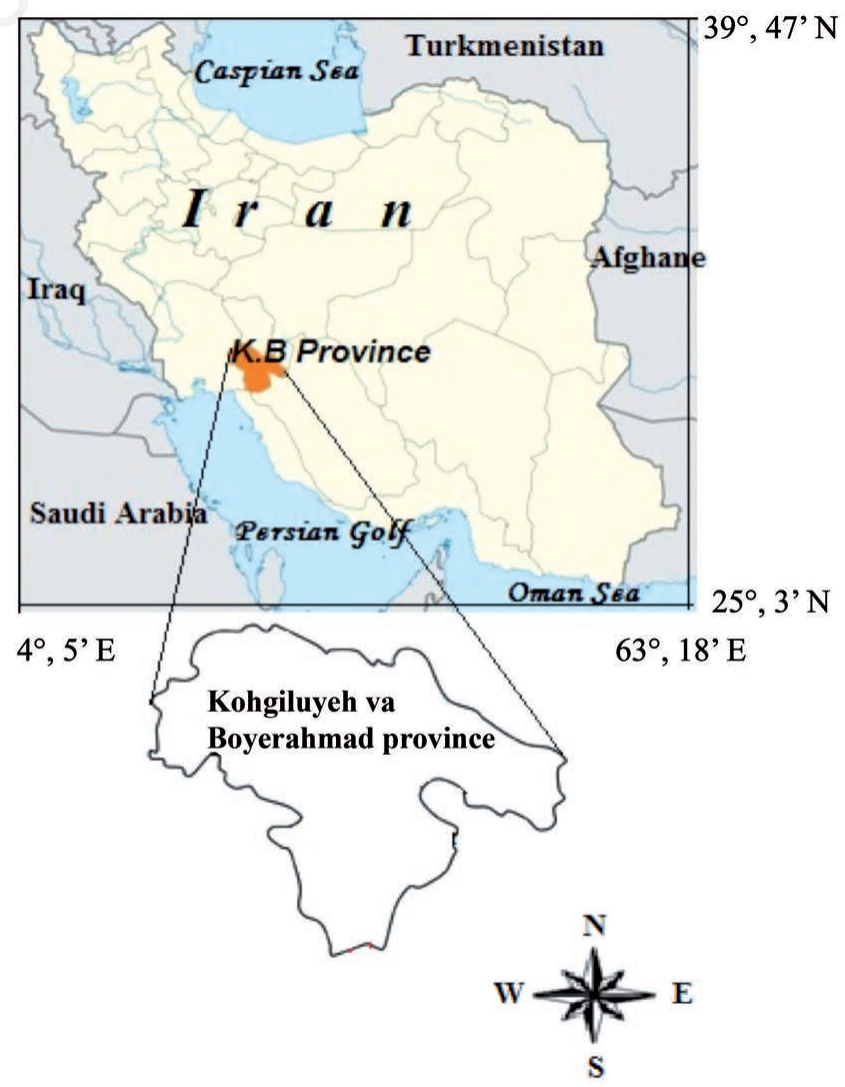

Figure 1. The geographical position of Kohgiluyeh va Boyerahmad province on map of Iran. 
Table 1. Overall populations of insect species associated with safflower in Gachsaran, Basht and Lishter areas.

\begin{tabular}{|c|c|c|c|c|}
\hline S. No. & Order: Family & $\begin{array}{l}\text { Gachsaran } \\
\text { Total }\end{array}$ & $\begin{array}{l}\text { Basht } \\
\text { Total }\end{array}$ & $\begin{array}{l}\text { Lishter } \\
\text { Total }\end{array}$ \\
\hline 1 & $\begin{array}{l}\text { Coleoptera: Bruchidae } \\
\text { a. Spermophagus sericeus }\end{array}$ & 5 & 17 & 0 \\
\hline 2 & $\begin{array}{l}\text { Coleoptera: Coccinelidae } \\
\text { a. Adalia bipunctata } \\
\text { b. Adalia decimpunctata } \\
\text { c. Coccinella septempunctata } \\
\text { d. Coccinella undecimpunctata } \\
\text { e. Exochomus nigromaculatus } \\
\text { f. Hippodamia convergens } \\
\text { g. Hippodamia tredecimpunctata } \\
\text { h. Hippodamia variegata } \\
\text { i. Oenopia conglobata } \\
\text { j. Psyllobora vigintiduopunctata } \\
\text { k. Scymnus syriacus }\end{array}$ & $\begin{array}{c}4 \\
0 \\
8 \\
19 \\
0 \\
9 \\
50 \\
16 \\
44 \\
11 \\
3\end{array}$ & $\begin{array}{c}10 \\
7 \\
16 \\
57 \\
14 \\
15 \\
70 \\
34 \\
42 \\
18 \\
12\end{array}$ & $\begin{array}{c}0 \\
2 \\
0 \\
15 \\
23 \\
20 \\
27 \\
26 \\
0 \\
17 \\
10\end{array}$ \\
\hline 3 & $\begin{array}{l}\text { Coleoptera: Curculionidae } \\
\text { a. Apion aestivum } \\
\text { b. Larinus flavescens } \\
\text { c. Larinus liliputanus } \\
\text { d. Sitona humeralis } \\
\text { e. Sitona puncticollis }\end{array}$ & $\begin{array}{c}10 \\
24 \\
0 \\
18 \\
11\end{array}$ & $\begin{array}{c}18 \\
45 \\
0 \\
12 \\
5\end{array}$ & $\begin{array}{c}26 \\
21 \\
10 \\
7 \\
0\end{array}$ \\
\hline 4 & $\begin{array}{l}\text { Coleoptera: Dermestidae } \\
\text { a. Anthrenus sp. } \\
\text { b. Anthrenus verbasci } \\
\text { c. Anthrenusvorax } \\
\text { d. Athagenus sp. }\end{array}$ & $\begin{array}{c}0 \\
5 \\
11 \\
9\end{array}$ & $\begin{array}{c}12 \\
7 \\
11 \\
16\end{array}$ & $\begin{array}{c}13 \\
20 \\
0 \\
21\end{array}$ \\
\hline 5 & $\begin{array}{l}\text { Dermaptera: Forficulidae } \\
\text { a. Forficula auricularia }\end{array}$ & 16 & 24 & 20 \\
\hline 6 & $\begin{array}{l}\text { Diptera: Tephritidae } \\
\text { a. Acanthiophilus helianthi } \\
\text { b. Chaetrollia carthami } \\
\text { c. Terellia luteolla }\end{array}$ & $\begin{array}{l}18 \\
30 \\
31\end{array}$ & $\begin{array}{c}5 \\
10 \\
25\end{array}$ & $\begin{array}{l}15 \\
10 \\
34\end{array}$ \\
\hline 7 & $\begin{array}{l}\text { Hemiptera: Anthocoridae } \\
\text { a. Anthocoris nemoralis } \\
\text { b. Anthocoris nemorum } \\
\text { c. Orius sp. }\end{array}$ & $\begin{array}{l}14 \\
0 \\
9\end{array}$ & $\begin{array}{c}23 \\
9 \\
13\end{array}$ & $\begin{array}{c}0 \\
0 \\
13\end{array}$ \\
\hline 8 & $\begin{array}{l}\text { Hemiptera: Aphididae } \\
\text { a. Aphis gossypi } \\
\text { b. Aphis nerii } \\
\text { c. Brachycaudus helichrysi } \\
\text { d. Eucarazzia elegans } \\
\text { e. Hyadaphis sphondyti } \\
\text { f. Pleotrichophorus grandolosus } \\
\text { g. Uroleucon compositae }\end{array}$ & $\begin{array}{c}53 \\
53 \\
50 \\
21 \\
55 \\
45 \\
0\end{array}$ & $\begin{array}{l}41 \\
40 \\
65 \\
20 \\
63 \\
40 \\
25\end{array}$ & $\begin{array}{c}40 \\
55 \\
30 \\
0 \\
50 \\
45 \\
0\end{array}$ \\
\hline 9 & $\begin{array}{l}\text { Hemiptera: Callaphididae } \\
\text { a. Ephedraphis ephedrae }\end{array}$ & 25 & 15 & 10 \\
\hline 10 & $\begin{array}{l}\text { Hemiptera: Cicadellidae } \\
\text { a. Austroagalia sinuata } \\
\text { b. Circulifer haematoceps } \\
\text { c. Empoasca sp. } \\
\text { d. Euscelis alsius } \\
\text { e. Macrosteles laevis } \\
\text { f. Neoaliturus fenestratus } \\
\text { g. Psammotettix striatus }\end{array}$ & $\begin{array}{c}40 \\
30 \\
17 \\
0 \\
36 \\
37 \\
29\end{array}$ & $\begin{array}{c}30 \\
16 \\
28 \\
0 \\
42 \\
63 \\
43\end{array}$ & $\begin{array}{c}42 \\
0 \\
17 \\
40 \\
0 \\
42 \\
20\end{array}$ \\
\hline 11 & $\begin{array}{l}\text { Hemiptera: Diaspididae } \\
\text { a. Parlatoria ephedrae }\end{array}$ & 0 & 15 & 0 \\
\hline 12 & $\begin{array}{l}\text { Hemiptera: Lygaeidae } \\
\text { a. Lygus sp. } \\
\text { b. Oxycarenus hyalipennis } \\
\text { c. Oxycarenu palens }\end{array}$ & $\begin{array}{l}14 \\
10 \\
12\end{array}$ & $\begin{array}{c}20 \\
7 \\
12\end{array}$ & $\begin{array}{c}20 \\
10 \\
3\end{array}$ \\
\hline 13 & $\begin{array}{l}\text { Hemiptera: Miridae } \\
\text { a. Myrmecoris gracilis } \\
\text { b. Myrmecoris sp. }\end{array}$ & $\begin{array}{c}14 \\
4\end{array}$ & $\begin{array}{c}0 \\
10\end{array}$ & $\begin{array}{l}3 \\
9\end{array}$ \\
\hline
\end{tabular}

$\begin{array}{rr}\text { S. No. Order: Family } & \begin{array}{c}\text { Gachsaran Basht lishter } \\ \text { Total Total Total }\end{array}\end{array}$

14 Hemiptera: Pentatomidae a. Andralus sp.

15 Hemiptera: Reduviidae a. Reduvius personatus b. Reduvius sp. $0 \quad 7 \quad 0$

16 Hymenoptera: Braconidae

$\begin{array}{llll}\text { a. Bracon hebetor } & 6 & 5 & 5\end{array}$

b. Bracon luteator

$3 \quad 2 \quad 5$

\begin{tabular}{lllll}
17 & $\begin{array}{l}\text { Hymenoptera: Cynipidae } \\
\text { a Isocolus tinctorius }\end{array}$ & 4 & 7 & 8 \\
\hline 18 & Hymenoptera: Eulophidae & &
\end{tabular}

$\begin{array}{llll}\text { a. Pronotalia carlinarum } & 6 & 5 & 5 \\ \text { b. Pronotalia sp. } & 5 & 8 & 5\end{array}$

\begin{tabular}{lllll}
19 & $\begin{array}{l}\text { Hymenoptera: Eurytomodae } \\
\text { a. Eurytoma acroptilae }\end{array}$ & 6 & 7 & 6 \\
\hline 20 & Hymenoptera: Pteromaldae &
\end{tabular}

20 Hymenoptera: Pteromalidae

$\begin{array}{lccc}\text { a. Coletrechnus sp. } & 6 & 3 & 3 \\ \text { b. Coletrechnus viridis } & 5 & 7 & 7 \\ \text { c. Pachyneuron concolor } & 11 & 7 & 12 \\ \text { d. Pteromalus } \text { sp. } & 5 & 5 & 7\end{array}$

\begin{tabular}{lllll}
21 & & & \\
& Hymenoptera: Torymidae & 68 & 42 & 63 \\
& $\begin{array}{l}\text { a. Antistrophoplex conthurnatus } \\
\text { b. Microdontomenus annulatus }\end{array}$ & 14 & 16 & 19 \\
\hline $22 \quad \begin{array}{l}\text { Lepidoptera: Geometridae } \\
\text { a. Acontia groelis }\end{array}$ & 0 & 5 & 0
\end{tabular}

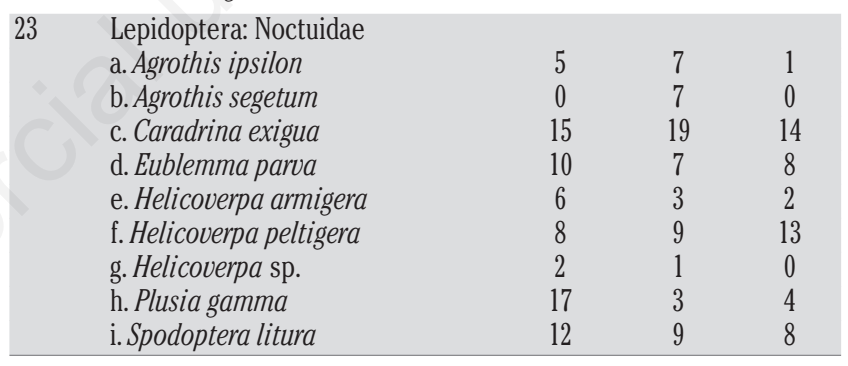

$24 \quad$ Lepidoptera: Nymphalidae a. Argyreus hyperbius

b. Junonia hierta

c. Nymphalis xanthomolus

d. Sphingonotus sp.

e. Vanessa indica

\begin{tabular}{|c|c|c|c|c|}
\hline 25 & $\begin{array}{l}\text { Lepidoptera: Papilionidae } \\
\text { a. Papilio demoleus } \\
\text { b. Papilio polyctor }\end{array}$ & $\begin{array}{l}7 \\
8\end{array}$ & $\begin{array}{l}3 \\
6\end{array}$ & $\begin{array}{l}5 \\
8\end{array}$ \\
\hline 26 & $\begin{array}{l}\text { Lepidoptera: Pieridae } \\
\text { a. Pieris brassicae } \\
\text { b. Pieris rapae }\end{array}$ & $\begin{array}{l}15 \\
19\end{array}$ & $\begin{array}{c}5 \\
13\end{array}$ & $\begin{array}{c}10 \\
5\end{array}$ \\
\hline
\end{tabular}

\begin{tabular}{lllll}
27 & $\begin{array}{l}\text { Lepidoptera: Saturnidae } \\
\text { a. Attacus atlas }\end{array}$ & 0 & 11 & 9 \\
\hline 28 & Orthoptera: Acrididae
\end{tabular}

28 Orthoptera: Acrididae

$\begin{array}{lccc}\text { a. Acrotylus sp. } & 11 & 12 & 0 \\ \text { b. Aiolopus sp. } & 9 & 4 & 7 \\ \text { c. Heteracris sp. } & 10 & 14 & 11 \\ \text { d. Sphingonotus sp. } & 16 & 0 & 8 \\ \text { Orthoptera: Gryllotalpidae } & & & \\ \text { a. Gryllotalpa gryllotalpa } & 20 & 19 & 29\end{array}$

\begin{tabular}{|c|c|c|c|c|}
\hline & a. Gryllotalpa gryllotalpa & 20 & 19 & 29 \\
\hline 30 & $\begin{array}{l}\text { Orthoptera: Mantidae } \\
\text { a. Mantis religiosa }\end{array}$ & 4 & 9 & 9 \\
\hline 31 & $\begin{array}{l}\text { Thysanoptera: Thripidae } \\
\text { a. Haplothrips sp. } \\
\text { b. Thrips tabaci }\end{array}$ & $\begin{array}{l}75 \\
53\end{array}$ & $\begin{array}{l}60 \\
90\end{array}$ & $\begin{array}{l}47 \\
40\end{array}$ \\
\hline & Number of insects & 1428 & 1619 & 1214 \\
\hline
\end{tabular}


(26.6), Noctuidae (25.0) and Torymidae (27.3) had higher population in the Gachsaran-safflower zone than in the Basht-safflower area with means of 92.3, 63.0, 42.6, 21.0, 21.6 and 19.3 respectively. Also the families like Nymphalide, Pieridae, Lygaeidae, Papilionidae, Miridae, Pentatomidae, Reduviidae, Geometridae, Gryllotalpidae, Mantidae, Acrididae, Saturnidae and Anthocoridae had mean population of 12.6, $7.4,12.0,4.1,4.4,8.6,1.9,0.5,7.5,2.4,11.3,3.3$ and 8.9 .

It is thus clear that all of these families had more population in the Gachsaran-safflower area and significantly differed from the Basht-safflower area. The minimum mean value of 0.5 specimens was given by the family Geometridae, which was statistically similar to most other families.

Since the identification of insect pests is one of the most efficient methods for pest management, an attempt was made to investigate insect fauna in the Iranian province of Kohgiluyeh va Boyerahmad. The results showed that safflower flies including: Acanthiophilus helianthi, Chaetorellia carthami and Terellia luteola, that larvae of which attack the flower heads and seeds are most important safflower pest in Iran. The insects occurring on flower heads of safflower were determined during this study. Also, Oxycarenus palens, Oxycarenus hyalipennis, Lygus sp. aphids and thripses were found on flower heads of safflower (Table 2).

The results indicate that various insect pests are active in the safflower fields, so due to the specific floristic and faunistic status, safflower has provided particular microclimate, which is the breeding ground for insects and arthropods. Successful and integrated pest management in oilseed farms will depend on multidisciplinary approaches and identification of insect fauna and arthropods. The results suggest that the precise and definite identification of the insects on the farming safflowers and the wild safflowers are particularly important and, in fact, it is the first step in executing the integrated management of the safflower pests. The results showed that from total of 4261 specimens of various insects were collected from safflower farms during 2008, comprised 19 families including chewing pest, sucking pests and plant feeders. Also, families such as, Pentatomidae, Miridae, Anthocoridae, Acrididae and Lygaeidae is saprophagous insects and active in safflower farms. Finally, 7 families comprised benefit insects (Natural enemies) including, predators and parasitoids.

The above results suggest that three the Gachsaran, Basht and Lishter areas acted as alternate hosts for different insects. The most serious insect pests of the major crops in experiments were present in the Gachsaran area, but they also used the Basht area as an alternate habitat.
Table 2. Comparison of means for families.

\begin{tabular}{|c|c|c|c|c|}
\hline Family & Gachsaran & Basht & Lishter & Mean: \\
\hline Aphididae & 98.0 & 92.3 & 73.3 & $87.6^{\mathrm{a}}$ \\
\hline Coccinellidae & 98.3 & 54.6 & 46.6 & $66.5^{\mathrm{b}}$ \\
\hline Cicadellidae & 74.0 & 63.0 & 53.6 & $63.5^{b}$ \\
\hline Thripidae & 50.0 & 42.6 & 29.0 & $40.5^{\mathrm{c}}$ \\
\hline Torymidae & 27.3 & 19.3 & 27.3 & $24.6^{\mathrm{d}}$ \\
\hline Curculionidae & 26.6 & 21.0 & 21.3 & $22.9^{\mathrm{d}}$ \\
\hline Noctuidae & 25.0 & 21.6 & 16.6 & $21.1^{\mathrm{d}}$ \\
\hline Tephritidae & 13.3 & 26.3 & 19.6 & $19.7^{\mathrm{de}}$ \\
\hline Dermestidae & 15.3 & 8.3 & 18.0 & $13.8^{\mathrm{e}}$ \\
\hline Nymphalidae & 11.3 & 13.0 & 13.6 & $12.6^{\mathrm{e}}$ \\
\hline Lygaeidae & 13.0 & 12.0 & 11.0 & $12.0^{\mathrm{e}}$ \\
\hline Acrididae & 10.0 & 15.3 & 8.6 & $11.3^{\mathrm{e}}$ \\
\hline Anthocoridae & 15.0 & 7.6 & 4.3 & $8.9^{e}$ \\
\hline Pentatomidae & 7.3 & 9.0 & 9.6 & $8.6^{\mathrm{e}}$ \\
\hline Pteromalidae & 7.3 & 9.0 & 9.6 & $8.6^{\mathrm{e}}$ \\
\hline Gryllotalpidae & 6.3 & 6.6 & 9.6 & $7.5^{\mathrm{f}}$ \\
\hline Pieridae & 6.0 & 11.3 & 5.0 & $7.4^{\mathrm{f}}$ \\
\hline Forficulidae & 8.0 & 5.3 & 6.6 & $6.6^{\mathrm{g}}$ \\
\hline Callaphididae & 5.0 & 8.3 & 3.3 & $5.5^{\mathrm{fg}}$ \\
\hline Miridae & 3.3 & 6.0 & 4.0 & $4.4^{\mathrm{fg}}$ \\
\hline Papilionidae & 3.0 & 5.0 & 4.3 & $4.1^{\mathrm{fg}}$ \\
\hline Eulophidae & 4.3 & 3.6 & 3.3 & $3.7^{\text {gh }}$ \\
\hline Saturnidae & 3.6 & 0.0 & 3.0 & $3.3^{\text {gh }}$ \\
\hline Braconidae & 2.3 & 3.0 & 3.3 & $2.8^{\mathrm{h}}$ \\
\hline Bruchidae & 5.6 & 1.6 & 0.0 & $2.4^{\mathrm{h}}$ \\
\hline Mantidae & 3.0 & 1.3 & 3.0 & $2.4^{\mathrm{h}}$ \\
\hline Eurytomidae & 0.0 & 3.6 & 3.0 & 3.3 \\
\hline Cynipidae & 2.3 & 1.3 & 2.6 & $2.1^{\mathrm{h}}$ \\
\hline Reduviidae & 2.0 & 3.6 & 1.3 & $1.9^{\mathrm{h}}$ \\
\hline Diaspididae & 5.0 & 0.0 & 0.0 & $1.6^{\mathrm{h}}$ \\
\hline Geometridae & 1.6 & 0.0 & 0.0 & $0.5^{\mathrm{i}}$ \\
\hline
\end{tabular}

a-i Dissimilar letters in each column with using Duncan's test at level of 5\% together have significant differences.

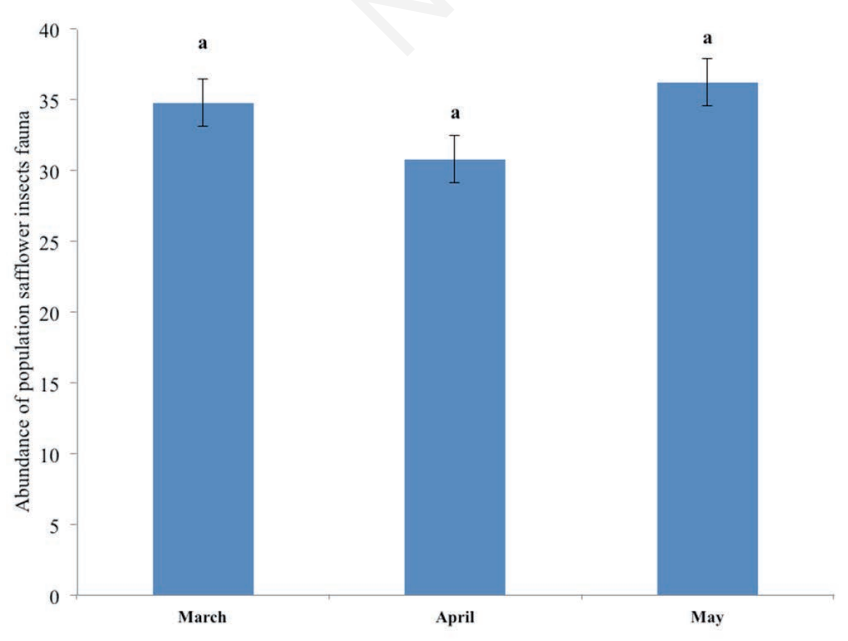

Figure 2. Comparison of means for months.

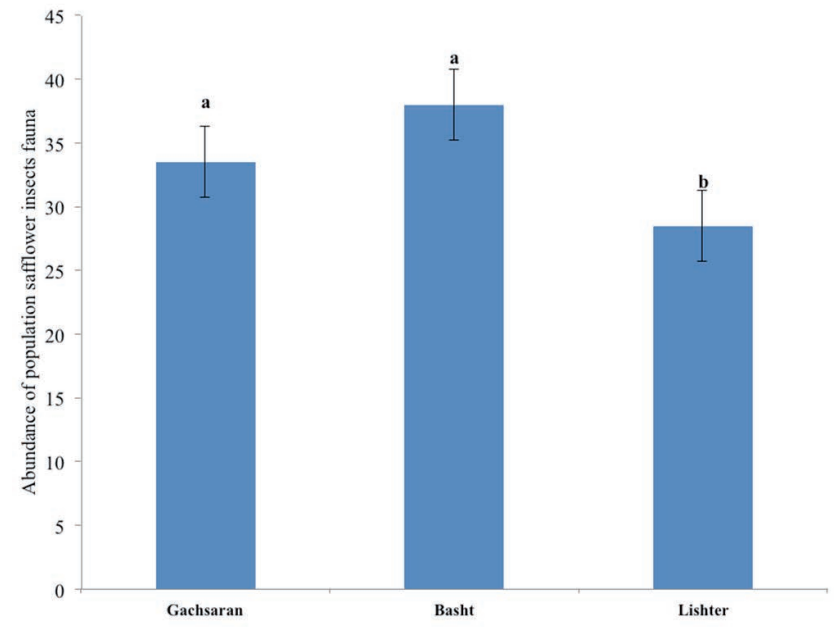

Figure 3. Comparison of means for localities. 
The maximum mean value of 87.6 specimens was obtained for the family Aphididae, which had significant difference with other families. The minimum mean value of 0.5 was achieved in the family Geometridae and it was statiscally similar to most of other families.

The above results cannot be compared with those of Ashri (1971), Hegazi and Moursi (1983), Talpur et al. (1995) and Campobasso et al. (1999), who collected and identified many different families and species without mentioning the number of species and families and their population in different localities. These results are not in conformity.

\section{Conclusions}

It should be reminded that the precise and definite identification of the insects on the farming safflowers and the wild safflowers are particularly important and, in fact, should be considered as the first step in executing the integrated management of the safflower pests.

Considering the policy for an increase in the cultivation area of safflowers, it is necessary to identify the fauna of the insects of this plant so that suitable methods for the control of the pests can be achieved and appropriate measures for the integrated management can be taken. Accordingly, the collection and identification of some of these species were conducted; however, this technique still needs further development.

Safflower is a highly valued oilseed, extensively cultivated in warm temperate and cool subtropical regions. Due to its specific floristic and faunistic status, the safflower has provided particular microclimate, which is the breeding ground for insects and arthropods. Successful and integrated pest management in oilseed farms will depend on multidisciplinary approaches and identification of fauna insects and arthropods. The results suggest that the precise and definite identification of the insects on the farming safflowers and the wild safflowers are particularly important and, in fact, it is the first step in executing the integrated management of the safflower pests.

\section{References}

AHMED A., SUHAIL A., ABDIN Z., IFTIKHAR S. ZAHOOR K., 2004 Biodiversity of insects associated with sugarcane crop in Faisalabad. - Pak. J. Entomol. 26: 65-69.

AKASHE V.B., GHADGE S.M., GUD M.A., INDI D.V., DESHPANDE A.N., 2008 - Role abiotic components on the development of safflower aphid. - J. Maha. Agric. Univ. 33: 125-126.

ANON 1987- Safflower descriptor. - IBPGR Secretariat, Rome.

ASHRI A., 1971 - Evaluation of the world collection of safflower, Carthamus tinctorius L. II. Resistance to the safflower fly, Acanthiophilus helianthi R. - Euphytica. 20: 410-415.

BEHDAD E., 1989 - The pest of farming plants of Iran. - Neshat publications, Isfahan: $618 \mathrm{pp}$.
BHARAJ G.S., DESHPANDE S.L., SAXENA M.K., 2003 - Field screening of safflower genotypes for resistance against safflower aphid. National Seminar: Stress Mgmt. Oilseeds, International Seminar Oil Research, January 28-30.

BORROR D., DELONG D., TRIPLEHORN C.A., 1989 - An introduction to the study of insects. - Academic Press, London.

CAMPOBASSO G., COLONNELLI E., KNUTSON E., TERRAGITTI L., CRISTOFARO M., 1999 - Wild plants and their cited insects in the region, primarily Europe and the Middle East. - USDA-ARS 147: $429 \mathrm{pp}$.

GHARALI B., JO0ZIAN E., 2001 - A report on the species Chaetorellia carthami Stackelberg, 1929 (Dep.: Tephritidae) from Iran. - J. Entomol. Soc. Iran. 21: 1010-1018.

GIRAY H., 1979 - Investigations on the species and the food plants of the family Trypetidae (fruit-flies) attacking cultivated plants in the Aegean region. - Ege. Univ. Zir. Fak. Yayn. N/126, VI + 61 PP. Izmir.

GULLAN P.G., CRANSTON P.S., 2005 - The insects: an outline of entomology. - Blackwell Publishing, Malden.

HEGAZI E.M., MOURSI K.S., 1983 - Studies on the distribution and biology of capsule fly, Acanthiophilus helianthi Rossi on wild plants in Egyptian western desert. - Z. Angew. Ent. 96: 333-336.

HEYWOOD V.H., 1996 - The global biodiversity assessment. - The Globe 30: 2-4.

ISHAQ M., USMAN M., ASIF M., KHAN I.A., 2004 - Integrated pest management of mango against mealy bug and fruit fly. - Inter. J. Agri. Biol. 63: 452-455.

MODARESSAVAL M.A., 1994 - List of the agricultural pest of Iran and their natural enemies. - Ferdousi University of Mashhad. No. 127: 364 pp.

NASREEN A., CHEEMA G.M., FAREED S., SALEEM M.A., 2004 Resistance of different cotton cultivars to chewing insect pests. Pak. J. Entomol. 26: 81-85.

SAKRA E., 1999 - Productive possibilities of safflower in Tuscany. Inform. Agron. 55: 45-52.

SELIM A. A., 1978 - Insect pests of safflower (Carthamus tinctorius) in Musol, northern Iraq. - J. Agric. 12: 75-78.

SPELLERBERG I., FEDOR P.J., 2003 - A tribute to Claude Shannon (1916-2001) and a plea for more rigorous use of species richness, species diversity and the Shannon-Wiener index. - Glob. Ecol. Biogeogr. 12: 177-179.

SWIFT M.J., INGRAM J.S.I., 1996 - Effects of global change on multispecies agroecosystems. Global change \& terrestrial ecosystems; Report \#13. - NERC Centre for Ecology \& Hydrology Maclean Build, Wallingford: 56 .

TALPUR M.A., HUSSAN T., RUSTAMANI M. A., GAAD M.A., 1995 Relative resistance of safflower varieties to safflower shootfly, Acanthiophilus helianthi Rossi (Diptera: Tephritidae). - Proc. Pak. Congr. Zool. 15: 177-181.

WAY M.J, HEONG K.L., 1994 - The role of biodiversity in the dynamics and management of insect pests of tropical irrigated rice-a review. - Bull. Entomol. Res. 84: 567-587. 